\title{
ICT Challenges and Issues in Climate Change Education
}

\author{
Adriana ALEXANDRU, Marilena IANCULESCU, Eleonora TUDORA, Ovidiu BICA \\ National Institute for Research and Development in Informatics, \\ 8-10 Averescu Avenue, 011455 Bucharest 1, Romania, \\ adriana@ici.ro,manina@ici.ro,gilda@ici.ro,ovi@ici.ro
}

\begin{abstract}
Climate change is likely to define the global concern of the $21^{\text {st }}$ century. This concern is a huge educational challenge which relates to the global aim of the educational network founded by Changing with the Climate project that is discussing, learning, engaging and committing students from secondary as well as primary schools to undertake actions for limiting the change in climate. As specific aspects and impacts of climate change are discussed in various academic disciplines such as: Physics, Chemistry, Biology, Geography and Citizenship, the primary objective is to adopt a more holistic approach and link the teaching of all these issues from multidisciplinary perspectives. Thus, science may become more interesting and applicable to everyday life. This paper analyses the ICT challenges emerging from this type of approach.
\end{abstract}

Keywords: climate change, renewable energy sources, Education for Sustainable Development, Life Long Learning, eLearning, role of ICT in education.

\section{Introduction}

The impact of global warming arises primarily from our usage of fossil fuels at local level such as in heating our homes or providing our transport, as a by-product of their combustion being carbon dioxide. It is this gas together with other greenhouse gases which congregate in the upper atmosphere and by absorbing some of the earth's radiation, results in global warming. Consequently changing with the climate is the global concern of the $21^{\text {st }}$ Century. The world is likely to build so many fossil-fuelled power stations, energy guzzling factories and inefficient buildings in the next five years that it will become impossible to hold global warming to safe levels, and the chance of combating dangerous climate change will be lost forever.

The Changing with the Climate Network is a Comenius funded educational network linking schools across Europe to enhance teaching and learning and to encourage positive action in response to climate change. The network proposes an increased emphasis on actions to mitigate the extent of climate change by reducing those aspects of our behavior that negatively affect climatic conditions as well as our ecosystems, and, where possible, to adopt a lifestyle that will enable us to adapt to the inevitable changes. A major target of this increased emphasis will be the school-going population because it is the world youth who will be most directly affected. The challenges for using an ICT based approach is analyzed bellow.

\section{Background}

Climate change is defined as a change in the statistical properties of the climate system when considered over long periods of time [1]. The term sometimes is used to refer specifically to climate change caused by human activity, as opposed to changes in climate that may have resulted as part of natural processes on Earth [2]. In this sense, the human activity alters the composition of the global atmosphere, which is in addition to natural climate variability observed over comparable time periods [3]. Global climate change is caused by the accumulation of greenhouse gases in the lower atmosphere, caused especially by the combustion of fossil fuels. The atmospheric concentration of carbon dioxide, the main greenhouse gas, has increased by 30 percent since preindustrial times [4]. Climate change is one of the most critical challenges facing humanity abilities to achieve sustainable development goals, being a global problem that requires global solutions.

The United Nations Framework Convention on Climate Change [4] was signed by 155 countries at a conference in Rio de Janeiro in June 1992, with agreements on reduction of greenhouse gas emissions, thus enabling economic development to proceed in a sustainable manner.

Adopted in December 1997, the Kyoto Protocol strengthens the global response to climate change. It entered into force on 16 February 2005, setting binding targets for 37 industrialized countries and the European community for reducing greenhouse gas (GHG) 
emissions by on average $5.2 \%$ against 1990 levels by 2012 .

On March 2007, the European Council set up the energy and climate change-related objectives: reduction of greenhouse gas emissions by $20 \%$, integration by $20 \%$ of renewable energy sources into the final energy mix in the EU and reduction by $20 \%$ of $\mathrm{EU}$ primary energy use by 2020 . The targets set for the Member States to reduce greenhouse gas emissions in 2020 can be achieved by reducing energy consumption and by using a higher proportion of renewable energy.

In 2009, these targets were incorporated into the Climate and Energy Package by the European Parliament and Council with targets for Member States.

Following these agreements, there have been annual meetings of the partners to the Convention in various parts of the world, one of the most recent being held in Durban, South Africa in December 2011 as the international community's response to climate change. It was stated that all "developed and developing countries will for the first time work on an agreement that should be legally binding, to be written by 2015 and to come into force after 2020" [5].

The reduction of greenhouse gas emissions could be accomplished by increasing the use of Renewable Energy Sources (RES). In the Renewable Energy Directive from 2009, all European Member States agreed to increase the share of renewable energy in gross final energy consumption in such a way that for the 27 Member States the share would be $20 \%$ by 2020 [6]. The renewable energy share of gross final energy consumption amounts to $13.4 \%$ in 2011 against $12.5 \%$ in 2010.

For Romania, the Energy strategy of Romania for $2007-2020$ [7] promoted the electricity produced from renewable energy sources as a high priority of now-a-days. The shares of renewable energy in the national gross final energy consumption in 2011 is $24.1 \%$, the indicative trajectory for $2011-2012$ is $19.0 \%$ and the renewable energy target for the year 2020 is set at $24 \%$ (according to the Directive $2009 / 28 / \mathrm{EC}$ on the promotion of the use of energy from RES).

Increasing attention to climate change has underscored the need for approaches to education that equip and empower people of all ages to deal with uncertain environmental, economic and political futures [8]. Building the capacity for a future-orientated thinking is a key task of education [9]. The idea of Education for Sustainable development (ESD) was developed in the 1990s through Caring for the Earth: a strategy for sustainable living [10], the 1992 Earth Summit in Rio, and Agenda 21 [11]. The United Nations (UN)' millennium development goals, agreed in 2000, have since become seen as core ESD concerns, and the Johannesburg World Summit in 2002 stimulated the UN Decade for ESD (20052014), with four key objectives [12]: facilitating networking and collaboration among stakeholders in ESD; fostering greater quality of teaching and learning of environmental topics; supporting countries in achieving their millennium development goals through ESD efforts; and providing countries with new opportunities and tools to reform education.

The Strategy for Sustainable Development in Romania [13] promotes Education for Sustainable Development as integrated across all training programs. ESD can be done through formal, informal and non-formal paradigms. It requires cooperation and partnership between multiple decision makers: central and local authorities, education and scientific bodies, non-governmental organizations, local communities, citizens and international organizations. ESD capitalizes proactive participation and promotes volunteering as an expression of citizenship acquired with the support of the school. As part of ESD, environmental education is an objective which is found in all disciplines. It requires an interand trans-disciplinary approach in integrated educational formulas, cross-curricular and complementary resources.

The use of Information and Communication Technology (ICT) in education and training has been a key priority in most EU countries in the last decade. The integration of ICT in education promotes autonomous learning, curriculum differentiation [14], studentcentered learning, higher order thinking, problem-solving, cooperative learning [15], [16], clarification of abstract concepts and transformation of the understanding of the subject matter [17]. Despite the potential advantages of ICT use, the relationship between the use of ICT and educational 
performance is unclear [18], [19]. In some countries ICT are being integrated in the teaching-learning process in schools demonstrating high levels of effective and appropriate ICT use to support teaching and learning across a wide range of subject areas. However, in other countries schools are in the early phase of adopting ICT, characterized by important enhancements of the learning process, some developments of e-learning (ICT-enabled learning), but without any profound improvements in learning and teaching [20].

According to [21] and [22], eLearning is defined as being "knowledge delivered by online services as education and training". In education, eLearning is a technique to enhance learning and teaching experiences and is used to educate students with or without their instructors through any type of digital media [23]. E-learning can either be used to replace traditional face-to-face teaching completely or only partially to support traditional methods with access to complementary electronic information and possibilities to communicate [24]. Nowadays, the combination of traditional teaching with ITC is often used in schools.

\section{Problem Formulation}

In this context, Changing with the Climate educational network (CwC), which was initiated by a grant from the Life Long Learning programme of the EACEA agency, was launched with the aim of encouraging positive action of schools in response to climate change. This educational network has linked schools across Europe in enhancing teaching and learning and encouraged positive action in response to climate change.

There are six founding partners of the network located in six countries in southern and middle Europe: Institute of Education at University of Reading (England) - which is the lead partner in the network-, Ecoserveis (Barcelona, Spain), ICI (National Institute for Research and Development in Informatics, Bucharest, Romania), Comune di Bologna (Italy) Environmental Department, Regional Environmental Centre for Central and Eastern Europe (Szentendre, Hungary), and Hespul (Villeurbanne, France).

Schools face the challenge of including within their school curriculum the education for sustainable development, of which climate change is a priority topic. Outcomes of such network activities within these schools include:

- Identifying a common concern about the current impact of our lifestyle on our climate and a common vision that a change is required;

- Collating suitable resources for teaching and learning about climate change and trialling innovative pedagogical methods for climate change education;

- Recruiting schools in 6 countries (UK, FR, IT, ES, HU and RO) and twinning schools across country boundaries to share observations and experiences;

- Willingness of students and teachers to initiate local actions.

The network has 3 key aims [25]:

A. Developing an EU wide network of schools with an emphasis on sharing experiences and examining how diversity and culture influence our actions;

B. Enhancing teaching and learning experiences by providing access to a wide range of teaching resources, supporting and providing training for teachers, making science learning interesting, developing new teaching approaches and embed climate change in the curriculum;

C. Encouraging positive action to help limit changes in climate. Collective and individual action to tackle climate change is a key element of the project. Schools can act as a catalyst for action, to encourage whole community involvement, to engender lifelong learning and develop life skills.

\section{ICT as a Driver for Creating Learning and Innovative Education in Climate Change}

In the context of encouraging positive action in response to climate change, different types of education are necessary, intended for individuals, groups, organizations and communities. This approach is linked to the awareness of the causality relations existing among the environment, economic and social factors and the development and implementation of educational and public awareness programmes on climate change and its efects. This evolution represents a carrying 
off from the traditional role of education in this specific domain - mainly orientated towards the changing of the individual deviating behaviors - and which is playing now the role of a potential force for changing the way information is disseminated and managed in order to encourage positive action in response to climate change.

Information literacy is the set of skills needed to find, retrieve, analyze, and use information. The beginning of the 21 st century has been called the Information Age because of the explosion of information output and information sources. It has become increasingly clear that students cannot learn everything they need to know in their field of study in a few years of school. Information literacy equips them with the critical skills necessary to become independent lifelong learners [26], [27].

Information literacy is compulsory determined nowadays taking into consideration the ICT literacy. ICT literacy is defined as using digital technology, communications tools, and/or networks to access, manage, integrate, evaluate, and create information in order to function in a knowledge society. This definition is also important in that it lists five critical components of ICT literacy, which represent a set of skills and knowledge presented in a sequence that suggests increasing cognitive complexity [28]:

- Access - knowing about and knowing how to collect and/or retrieve information;

- Manage - applying an existing organizational or classification scheme;

- Integrate - interpreting and representing information. It involves summarizing, comparing and contrasting;

- Evaluate - making judgments about the quality, relevance, usefulness, or efficiency of information;

- Create - generating information by adapting, applying, designing, inventing, or authoring information.

The strong relationship between Information literacy and ICT literacy has gained a growing importance in addressing challenges facing actual society problems like climate change, leading to the development of new tools able to contribute to the development of a climateliterate population.
In order to enhance students' improved adoption of better initiatives and programs for an increased awareness regarding the core ideas in climate and energy science, it is essential that new Information Systems for Climate Change Education should be designed, implemented and better integrated in the mass education process.

Providing young people with empowering and relevant education on disasters and climate change can reduce their vulnerability to risk while contributing to sustainable development for their communities. Thus, they can become real agents of change [29].

Informatics Systems for Climate Change Education can provide a holistic and comprehensive approach to mitigate the climate change negative effects, facilitating new opportunities for teaching, learning, research, or adopting new patterns of social behaviour. In the same time, for having an active role in the education process, they have to address some challenges and threats even from the designing phase.

\section{Challenges}

- Bridging the digital divide and bringing Informatics Systems for Climate Change Education to groups that have the greatest need;

- Directing users to high quality information and to teach them how to assess the quality of information;

- Guiding teachers and students to use specific information in educationally appropriate ways;

- Developing strategies to ensure high quality standards in the publication of web based information;

- Generating new web applications able to anticipate the long-term unexpected impacts of the climate change.

\section{Threats}

- Inadequate information on the best use of ICT and on how to incorporate climate change issues in education;

- Climate change information on the internet is of variable quality, overwhelming and often difficult to interpret;

- Low ICT literacy - a potential difficulty for users to understand specific 
information, better manage their own way of living, and make informed decisions about personal choices;

- The lack of adequate infrastructure in certain regions;

- The use of the Information Systems for Climate Change Education will work differently in different contexts, both geographically and over time.

\section{Opportunities}

- The emergence of identifying and delivering different types of information needed for effective adaptation to climate change;

- Institutional and individual capacity to deploy training programmes using eLearning methods;

- Students increasingly responsible for their decision-making regarding the protection of the environment;

- Guaranteed validity and consistency of the available information provided by the Information Systems for Climate Change Education;

- New methods for using more efficiently the energy resources;

- A strengthening of the teacher-student relationship in which information flows in both directions;

- Dissemination of research findings in the climate change domain;

- Collective actions for implementing a better energy-efficient behaviour;

- Raising awareness on the fact that ICT can decrease vulnerability both to natural climate instability and human-induced climate change.

In order to improve the use and dissemination of Informatics Systems for Climate Change Education, a number of important factors must be taken into consideration and solved during their designing and implementation:

- Interoperability - a key enabler for the seamless transfer of specific information and data along the continuum of education process;

- Identification of information problems that are unique to climate change domain;

- Standardization of terminology;

- $\quad$ Easy access to other web applications;
- Affordability and ease of use of equipment and services;

- Designing user-friendly interface for transferring tailored information to users;

- Importance of motivation, culture, management of information, user involvement and acceptance and the usability of the technology;

- Specific levels of ICT literacy that allows the users to operate the informatics systems, retrieve and input information;

- A better management of the relationship between teachers and students.

\section{Climate Change is a Challenge, Teaching about it Demands Changes}

The changing with climate network is intended to develop the commitment of schools to introduce the topic in their teaching curricula, and making science lessons more interesting for the students. That requires developing teaching methodologies that provide learning based on linking causes and effects of climate change, using interactive and activity-oriented resources collated during the project.

Climate change is a global challenge where educators can take a significant role. Climate Change is not a simple topic to deal with: a comprehensive approach must include not only chemical, biological or technological aspects, but also historical, social, economical and even health ones. This cross-curricular approach of teaching climate change should facilitate the understanding of the extent of the problem and encourage the students to take actions to limit or mitigate climate change. For this purpose, it is also needed that teachers use innovative methodologies and try to develop student's critical awareness by encouraging their autonomy and acting more as a facilitator than as a source of knowledge. This changes the relationship between the students and the teachers particularly for students in secondary schools and requires a new approach towards teaching such topics. That involves a first stage of developing innovative teaching methodologies to teach this subject and stir student's interest in the topic, and a second stage where this interest results in the commitment to an action. Students benefit from a cross-curricular approach that offers a more 
complete view of the stakes we are facing as a society, and helps them understand the complexity of ecosystems and relations between humans and nature.

This approach has integrated features across the curriculum:

- Avoidance of the 'sage on the stage' model where the teacher gives minilectures, and the 'guide-on-the-side' model where the teacher provides resources (computer games, worksheets, card-sorts, text to read) and lets the students sort it out for themselves;

- Adoption of a teacher-participant approach where the teacher interacts with the students, especially through answering questions carefully provoked by resources or activity, posing carefully-framed questions designed to provoke discussion, especially in constructing communal actions to mitigate or adapt to climate change impacts, and providing materials to promote collaborative learning.

- Adoption of computer supported cooperative learning (CSCL) approach as a pedagogical approach wherein learning takes place via social interaction in the classroom learning environment using a computer or through the Internet. This kind of learning is characterized by the sharing and construction of knowledge among students using ITC as their primary means of communication or as a mean of common resource, thus affecting students' ability to generate new ideas and pass on knowledge [30]. CSCL is used in instructional plans in classrooms both traditional and online from primary to secondary schools. The process of planning and writing together articles for workshops or eco-magazines encourages students to express their ideas and develop a group understanding of Climate change matter. CWC network blog that combine free writing with communication tools has been used to share work, form ideas, and write synchronously. One section of the CWC network blog has therefore been created where students can record and share their observations about the changing climate with their twin class. Visual evidence is the easiest to share and can be easily transmitted.

- The teachers involved in the project are free to address climate change and energy with the eLearning resources and activities of their choice (selected by the consortium, others existing or activities they have conceived). Pedagogical resources have been selected for their quality and are available in different partner languages and website http://www.changingwithclimate.info.

Some are multilingual, others specific to one language. The resources that are listed are categorized into the following topics: causes of climate change including the use of predictive models, impacts of climate change including extreme weather events, energy sources and their environmental impact, sustainable use of energy including resource constraints, more efficient use of energy, application of renewable energy sources.

\section{Communicating the observations}

Students can share their experiences and views through several means: the CWC network blog, mail, videos, video-conferences, epostal cards, etc. The quarterly e-newsletter is also a means for the partner schools to share current news related to the topic, and a twitter account has been created also to provide news on the subject in a more dynamic basis.

\section{Pedagogical evaluation}

The evaluation methodology is based in carrying out a qualitative evaluation using surveys among the teachers involved in every country in order to gather standardized information of the relevant aspects of the pedagogical approach used, and identify the strengths and the weaknesses of different approaches.

Table 1. Schools involvement

\begin{tabular}{|c|c|c|c|c|}
\hline & $\begin{array}{c}\text { Age } \\
\text { Ranges }\end{array}$ & $\begin{array}{c}\text { No. of } \\
\text { Students }\end{array}$ & $\begin{array}{c}\text { No. of } \\
\text { Teachers }\end{array}$ & $\begin{array}{c}\text { No. of } \\
\text { Schools }\end{array}$ \\
\hline \multirow{3}{*}{ UK } & $5-11$ & 380 & 17 & 9 \\
& $12-16$ & 220 & 18 & 8 \\
& $17-19$ & 120 & 14 & 7 \\
\hline \multirow{2}{*}{ ES } & $10-11$ & 162 & 6 & 6 \\
& $12-14$ & 541 & 12 & 8 \\
\hline FR & & & & \\
\hline \multirow{3}{*}{ HU } & $5-11$ & 140 & 4 & 5 \\
& $12-16$ & 112 & 7 & 4 \\
& $17-19$ & 90 & 5 & 2 \\
\hline \multirow{3}{*}{ RO } & $5-11$ & 4 & 1 & 1 \\
& $12-16$ & 180 & 20 & 5 \\
\hline \multirow{2}{*}{ IT } & $17-19$ & 427 & 20 & 5 \\
& $11-13$ & 200 & 17 & 8 \\
\hline
\end{tabular}


The questionnaire is mainly composed of closed questions that require multiple choice answers or check-all-that-apply, in scale format, where teachers should decide to rate the sentence in along the scale continuum. This structure is designed to reflect the grade of agreement/disagreement or identification with a statement. However, the questionnaires include some open questions as well in order to gather a wider range of opinions and ideas to be taken into account.

The assessment criteria are: evaluation of the eLearning resources and activities used; evaluation of the twinning experience from a pedagogical, but also an operational point of view; assessing the specific pedagogical methodologies; and gathering information about the participation and commitment of the schools at the teaching stage of the project.

The analysis of all this data has provided us enough information to identify successful aspects of the approach and where improvements can be made. Fragmented results of the survey are presented in Figure 1. The results of the SWOT analysis are:

\section{Strengths:}

- Schools are using great diversity of Learning resources and activities;
- A lot of teamwork is being used, thus teaching students to work with each other in order to use CBCL facilities;

- Teachers are encouraging the autonomy of the students, so they are acting more as Facilitators;

- Students are interested in and motivated by the topic, so good learning results are being achieved;

- Twinning, using TIC facilities, is perceived as an enriching activity to teach the lessons, and is helping students to develop a global view of the problem and possible solutions;

- An interdisciplinary approach is being used, so students are encouraged to link a diversity of topics to climate change.

\section{Weaknesses:}

- There have been some difficulties with the twinning, mainly related to ICT problems and the frequency of communication between some twin schools, but also some delays in setting up the twinning between schools from different countries.

- Some linguistic problems related to the English language proficiency level in students from non-English speaking countries (especially at primary schools), that make it difficult to do online
RESOURCES
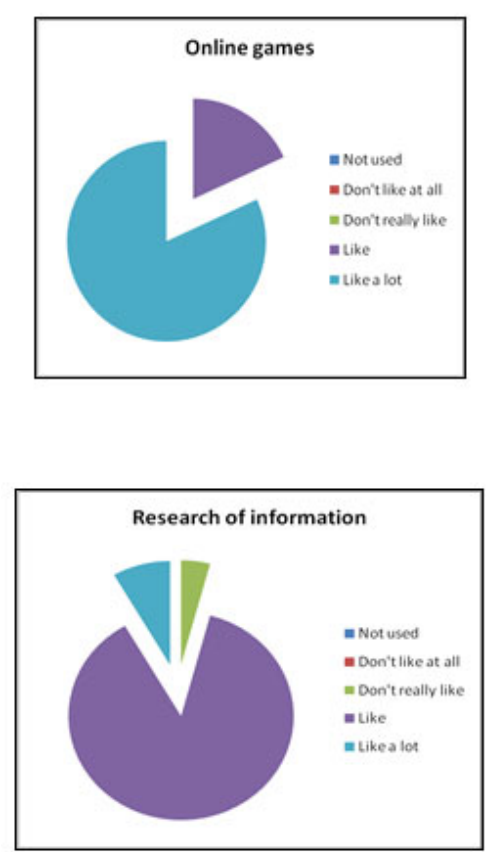

TWINNING

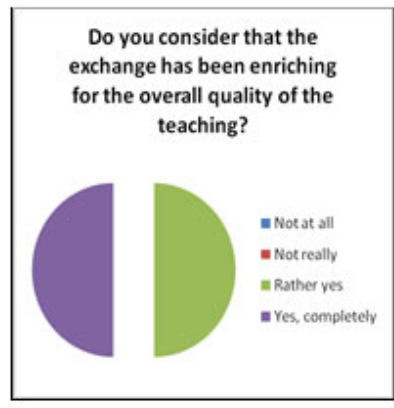

ACTIVITIES

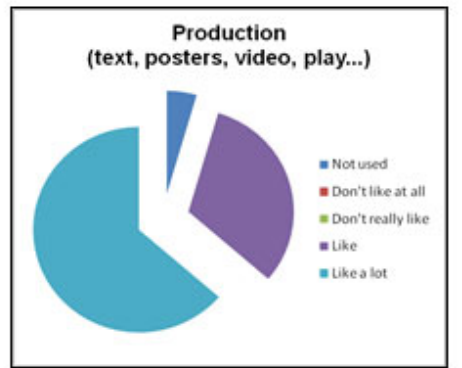

METHODOLOGY
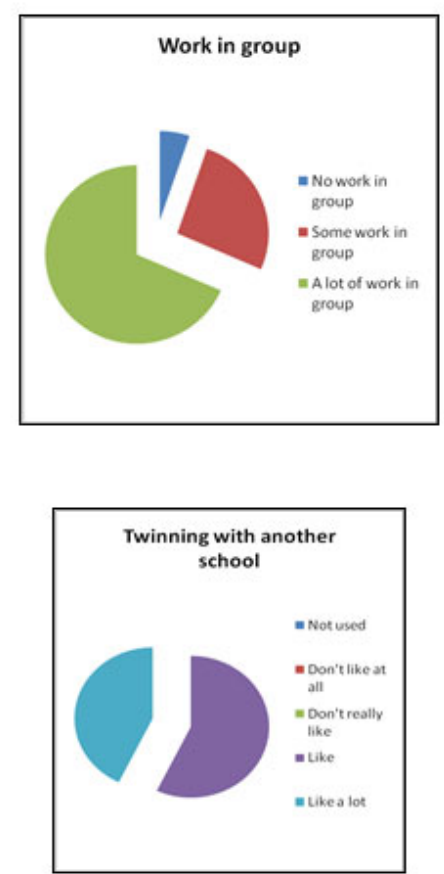

Figure 1. Fragmented results of the Romanian survey 
conferences with the students, and limit the exchanges to written and planned activities;

- Some teachers have to spend extra time to fit these activities with the pedagogical plans of their schools.

\section{Opportunities:}

- Takes advantage of new eLearning resources that the new schools and new organizations provide to the network;

- Uses the motivation of the students for the topic to involve more actors (parents, NPO's, etc) and set up local actions with more impact;

- Uses the differences between climatology conditions in the different countries to strengthen this global view of $\mathrm{CC}$ and show the need of international cooperation in the $\mathrm{CC}$ field and environmental issues in general;

- Strengthens the cross-curricular approach to show all CC dimensions and help students to develop a critical awareness concerning $\mathrm{CC}$ related topics.

\section{Threats:}

- Communication issues or insufficient knowledge of ICT tools may limit effective twinning;

- The difficulties to adapt climate change topics to the school pedagogical plan can discourage some teachers.

\section{Conclusions and Recommendations}

Resources. Students often seem to like the more dynamic resources like games (especially online games), experiments or exhibitions, instead of written materials (books, press articles, etc.). In relation to the kind of activities, students like better teamwork than individual work, and enjoy specially tasks related to the production of texts, videos, posters, etc.

Twinning. This is seen by the students as a likeable activity that motivates their attention. It seems an innovative and very appropriate tool to work on the climate change issue, as it provides a global view of the climate change topic and show the students the need of international cooperation in the field of environment. But it has experienced some difficulties to be carried out in an effective way. So, twinning is an activity that should be given more space, due to the motivation for the students involved and the learning they can get through it. But we must strengthen it, by providing more support and guidance to schools, including ICT support if teachers don't have enough knowledge of how to use some tools. There are some useful steps:

- development of web-based methodology to inform and motivate schools about activities and commitments on energy savings;

- sharing activities and the progress on implementation of commitments;

- running parallel activities, exhibition, games.

Methodologies. The results on methodologies used show that most of the teachers undertake the work in groups, but not much external collaboration (bringing experts, for example). At the classes, students act with some autonomy, although the teacher offers some information.

Innovative methodology has the next design:

- attractive and exciting teaching and learning based on TIC technologies;

- use "green lessons" entertaining, illustrative/informative (web based);

- promote computer supported co-operative learning;

- facilitate communication building social competences by using online communication facilities.

Impact on students. The results on the impact on students are good: they mostly show motivation for the project and they are acquiring quality learning related to climate change. They understand the overall impacts of $\mathrm{CC}$ and have learned many actions to limit or mitigate it. The next step would be to consolidate these attitudes and spread it to their social environment, which is supposed to be achieved through the local actions.

Innovation. Most teachers report that they have used a cross-sectional approach, linking climate change with different topics. Science is still the main subject used to teach it, but many schools also offer an historical perspective, use math statistics to be aware of the impacts, introduce some related health aspects, or even use it as a topic in art classes. 
The way forward is to keep promoting this cross-curricular approach to the topic, and encourage schools to involve different teachers and subjects in the teaching of climate change, encouraging so the students to establish links between the different aspects related to this topic, and helping them to develop a critical awareness.

\section{Acknowledgements}

This work was partly funded by the European Commission through Changing with the Climate project, in the framework of Comenius - LifeLong Learning programme. The authors gratefully acknowledge the contribution of their partner and associated partners as well as the teachers and students involved in the consolidation workshops and local actions

\section{REFERENCES}

1. Glossary - Climate Change. Education Center - Arctic Climatology and Meteorology. NSIDC National Snow and Ice Data Center. Glossary, in IPCC TAR WG1 2001.

2. http://nsidc.org/arcticmet/glossary/climate change.html.

3. Wikipedia, Climate change Available online: http://en.wikipedia.org/wiki/ Climate_change.

4. The United Nations Framework Convention on Climate Change. 21 March 1994. Available online: http://unfecc.int/essential_background/conv ention/background/items/1349.php.

5. The Guardian Durban conference 13 December 2011. Available online: http://www.theguardian.com/environment/ durban-climate-change-conference-2011.

6. The State of Renewable Energies in Europe': European Union renewable energy shares in 2011, including employment, turnover and highlights of seven EU regions, February 2013. Available online: http://www.eurobserver.org/pdf/bilan12.asp.

7. Strategia energetică a României pentru perioada 2007 - 2020 actualizată pentru Perioada 2011 - 2020 (in Romanian), Available at: http://www.minind.ro/energie/STRATEGI A_energetica_actualizata.pdf.
8. BANGAY, C., N. BLUM, Education Responses to Climate Change and Quality: Two Parts of the Same Agenda? International Journal of Educational Development, Volume 30, Issue 4, July 2010, pp. 359-368.

9. United Nations Education, Scientific and Cultural Organisation (UNESCO). Framework for a Draft International Implementation Scheme, 2003. Available online: http://portal.unesco.org/ education/en/ev.php-URL_ID $=23365 \& U$ RL_DO $=$ DO_TOPIC\&URL_SECTION $=2$ 01.html.

10. International Union for the Conservation of Nature. Caring for the Earth: A Strategy for Sustainable Living, UNEP, WWF: Gland, Switzerland, 1991.

11. World Commission on Environment and Development. Agenda 21-Sustainable development action program-Rio Declaration on Environment and Development, Proceedings of United Nation Conference on Environment and Development, New York, NY, USA, 14 June 1992; de Janeiro, R., Ed., 1993.

12. UK Department for Education, What is Sustainable Development?, 2013. Available at: http://www.education.gov. uk/a0070736/sd/

13. The Strategy for Sustainable Development in Romania, Available at: http://strategia.ncsd.ro/docs/sndd10.ro.pdf

14. SMEETS, E., Does ICT contribute to powerful learning environments in primary education, Computers \& Education vol. 44, no. 4, 2005, pp. 343355.

15. SMEETS, E., T. MOOIJ, Pupil-centred Learning, ICT, and Teacher Behaviour: Observations in Educational Practice, British Journal of Educational Technology, vol. 321, no. 4, 2001, pp. 403-417.

16. BANGERT, A., The Influence of Social Presence and Teaching Presence on the Quality of Online Critical Inquiry, Journal of Computing in Higher Education, vol. 20, no. 1, 2008, pp. 34-61.

17. LEACH, J., B. MOON, Pedagogy, Information and Technology and Teachers' Professional Knowledge, The Curriculum Journal, vol. 11, no. 3, 2000, pp. 385-404. 
18. ARISTOVNIK, A., The Impact of ICT on Educational Performance and its Efficiency in Selected EU and OECD Countries: A Non-parametric Analysis, The Turkish Online Journal of Educational Technology, volume 11, issue 3, 2012, pp. 144-152.

19. SHAIKH, Z., A., S. A. KHOJA, Role of ICT in Shaping the Future of Pakistani Higher Education System, The Turkish Online Journal of Educational Technology, volume 10, issue 1, 2011, pp. 149-161.

20. BALANSKAT, A., R. BLAMIRE, S. KEFALA, The ICT Impact Report: a Review of Studies of ICT Impact on Schools in Europe, Brussels: European Schoolnet, 2006.

21. FRY, K., Forum Focus and Overview, The Business of E-learning: Bringing your Organization in the Knowledge Economy, Telcam Group, University of Technology, Sydney, 2000.

22. WILD, R. H., K. A. GRIGGS, T. DOWNING, A Framework For eLearning as a Tool for Knowledge Management, Industrial Management \& Data Systems, volume 102, no.7, 2002, pp. 371-380.

23. CHRISTIE, M. F., F. FERDOS, The Mutual Impact of Educational and Information Technologies: Building a Pedagogy of e-Learning, Journal of Information Technology Impact, vol. 4(1), 2004, pp. 15-26.

24. PENNY, K. I., Factors that Influence Student E-learning Participation in a UK Higher Education Institution, Interdisciplinary Journal of ELearning and Learning Objects, vol. 7, 2011, pp. 81-95.
25. ALEXANDRU, A., E. TUDORA, O. BICA, R. MAYER, Experiences in Using Educational Resources on Climate Change Topics in Romanian Schools, ICSEEE 2013: International Conference on Sustainable Energy and Environment Engineering, Proceedings of World Academy of Science, Engineering and Technology (WASET), Issue 79, July 2013, Zurich, pISSN: 2010-376X, eISSN, 2010-3778, 2013.

26. The Association of College and Research Libraries (ACRL), Introduction to Information Literacy, Available at: http://www.ala.org/acrl/issues/infolit/overvi ew/intro

27. TUBA, M., I. MOISIL, , Apects Concerning Information Literacy in the $21^{\text {th }}$ Century, Studies in Informatics and Control, vol. 19, No. 2, June 2010, pp. 193-198.

28. A Report Of The International ICT Literacy Panel, Digital Transformation A Framework for ICT Literacy, Available at: www.ets.org/research/ ictliteracy

29. UNICEF Publications on Climate Change and Children, Climate Change and Environmental Education, Available at: http://www.unicef.org/education/bege_616 68.html

30. NICULESCU, A., G. THORSTEINSSON, Enabling Idea Generation through Computer-Assisted Collaborative Learning, Studies in Informatics and Control, vol. 20, No. 4, December 2011, pp. 403-410. 